\title{
Cytokeratin expression during mouse embryonic and early postnatal mammary gland development
}

\author{
Peng Sun $\cdot$ Yuanyang Yuan $\cdot$ Aihua Li $\cdot$ Boan Li $\cdot$ \\ Xing Dai
}

Accepted: 1 November 2009 / Published online: 25 November 2009

(C) The Author(s) 2009. This article is published with open access at Springerlink.com

\begin{abstract}
Cytokeratins are intermediate filament proteins found in most epithelial cells including the mammary epithelium. Specific cytokeratin expression has been found to mark different epithelial cell lineages and also to associate with putative mammary stem/progenitor cells. However, a comparative analysis of the expression of cytokaratins during embryonic and postnatal mammary development is currently lacking. Moreover, it is not clear whether the different classes of putative mammary stem/progenitor cells exist during embryonic development. Here, we use double/ triple-label immunofluorescence and immunohistochemistry to systematically compare the expression of cytokeratin 5 (K5), cytokeratin $6(\mathrm{~K} 6)$, cytokeratin $8(\mathrm{~K} 8)$, cytokeratin 14 (K14) and cytokeratin 19 (K19) in embryonic and early postnatal mouse mammary glands. We show that $\mathrm{K}^{+}$and $\mathrm{K} 8^{+} / \mathrm{K} 14^{+}$putative mammary progenitor cells arise during embryogenesis with distinct temporal and spatial distributions. Moreover, we describe a transient disconnection of the expression of $\mathrm{K} 5$ and K14, two cytokeratins that are often co-expressed, during the first postnatal weeks of
\end{abstract}

P. Sun and Y. Yuan contributed equally to this work.

P. Sun $\cdot$ Y. Yuan $\cdot$ A. Li $\cdot$ X. Dai $(\bowtie)$

Department of Biological Chemistry,

School of Medicine, University of California,

D250 Med Sci I, Irvine, CA 92697-1700, USA

e-mail: xdai@uci.edu

\section{Dai}

Developmental Biology Center,

University of California, Irvine, CA 92697, USA

Y. Yuan · B. Li

Department of Biomedical Sciences,

Key Laboratory of the Ministry of Education

for Cell Biology and Tumor Cell Engineering, Xiamen University,

Xiamen, Fujian 361005, People's Republic of China mammary development. Finally, we report that cytokeratin expression in cultured primary mammary epithelial cells mimics that during the early stages of postnatal mammary development. These studies demonstrate an embryonic origin of putative mammary stem/progenitor cells. Moreover, they provide additional insights into the use of specific cytokeratins as markers of mammary epithelial differentiation, or the use of their promoters to direct gene overexpression or ablation in genetic studies of mouse mammary development.

Keywords Cytokeratin $\cdot \mathrm{K} 5 \cdot \mathrm{K} 6 \cdot \mathrm{K} 8 \cdot \mathrm{K} 14 \cdot \mathrm{K} 19 \cdot$ Stem and progenitor cells $\cdot$ Mammary gland development

\section{Introduction}

Mammary gland arises from the multipotent surface ectoderm during embryogenesis (Veltmaat et al. 2003), relying on reciprocal epithelial-mesenchymal interactions for morphogenesis. In mice, mammary placode forms between E10.5 and E11.5, and progresses through bud (E12.5E15.5) and sprout (E16.5) stages to give rise to a rudimentary mammary tree before birth. Following birth, the mammary gland grows isometrically with the body, but expands rapidly via elongation and branching during puberty at around 3-7 weeks of age, culminating in a mature gland by approximately 10-12 weeks of age. Proliferation of mammary progenitor cells that reside in tips, or terminal end buds (TEB), of the elongating ducts facilitates such expansion (Ball 1998; Kenney et al. 2001; Woodward et al. 2005). During pregnancy, small structures bud off the ductal compartment and differentiate to form an expanded lobulo-alveolar compartment composed of basal myoepithelium and secretory luminal epithelium (Hennighausen 
and Robinson 2001). These lobulo-alveolar structures involute after lactation, to be rebuilt with each subsequent pregnancy. The recognition of this regenerative capacity led to the recent isolation of stem/progenitor cell-enriched populations from the mouse mammary epithelium (Shackleton et al. 2006; Stingl et al. 2006).

Cytokeratins are intermediate filament proteins found in most epithelial cells. Two types of cytokeratins exist and are often found as heterodimers between acidic type I cytokeratin (K9-K20) and basic or neutral type II cytocytokeratin (K1-K8) (Moll et al. 1982, 2008). Several cytokeratins are lineage markers within the mammary epithelium. Among these, both $\mathrm{K} 5$ and $\mathrm{K} 14$ are found to mark basal/ myoepithelial cells, where as K8/K18 expression marks luminal cells of mouse mammary gland (Mikaelian et al. 2006). There is also limited knowledge on the association of certain cytokeratin expression with a mammary stem/ progenitor cell state. Of particular note, $\mathrm{K} 6$ is regarded as a putative multipotent/bipotent mammary epithelial progenitor cell marker in mice due to its strong expression in the body cells of TEB, its transient expansion during early pregnancy, and its persistent although rare expression during pregnancy, lactation, and involution (Grimm et al. 2006; Sapino et al. 1993; Smith et al. 1990). K14 ${ }^{+} / \mathrm{K}^{+}$ suprabasal/luminal cells have been infrequently detected in adult mouse mammary glands and are proposed to be luminally restricted progenitor cells ( $\mathrm{Li}$ et al. 2007). K19 is considered a neutral switch cytokeratin the expression of which is compatible with cell type flexibility (Stasiak et al. 1989), and has been shown to be a luminal marker in human mammary glands (Bartek et al. 1990). Moreover, K14/K19-double positive transitional cells have been detected in adult human mammary glands and also proposed to be multipotent progenitor cells (Villadsen et al. 2007). However, whether such $\mathrm{K} 14^{+} / \mathrm{K} 19^{+}$cells also exist in mouse mammary glands has not been addressed. To date, a comprehensive knowledge of the expression of these cytokeratins during embryonic and early postnatal development is still lacking. Such information will facilitate our understanding of how lineage specification occurs during mammary development. Moreover, it will shed light into the embryonic origin of adult mammary stem/progenitor cells, a notion important not only for our fundamental understanding of epithelial stem cell biology, but also for studies of breast cancers, particularly those of a stem/ progenitor cell origin.

In this work, we use double- and triple-label immunofluorescence and immunohistochemistry to compare the expression of K5, K6, K8, K14 and K19 during mammary gland development. We show that $\mathrm{K}^{+}$, and $\mathrm{K} 8^{+} / \mathrm{K} 14^{+}$or $\mathrm{K} 14^{+} / \mathrm{K} 19^{+}$double positive cells arise during embryogenesis with distinct temporal and spatial distributions. Moreover, we report a transient separation of K5 and K14 expression during the first two postnatal weeks of development, with abundant $\mathrm{K}_{1} 4^{+}$but $\mathrm{K}^{-}$cells present in the suprabasal/luminal compartment. Finally, we analyze the expression of K5, K6, and K14 during growth and differentiation of primary mammary epithelial cells.

\section{Materials and methods}

Mice

Mice in a 129svXC57Bl/6 (129XB6) mixed genetic background were used for the study. Embryonic stages were determined according to the copulation plug date (E0.5 was counted as the first day a copulation plug was observed). For each experiment, multiple samples from at least two different animals were examined. All experiments have been approved by, and conform to the regulatory guidelines of the IACUC committee of University of California, Irvine.

Isolation and culturing of primary mammary epithelial cells

Primary mammary epithelial cells were isolated from 129XB6 hybrid mice as described (Gu et al. 2009) and cultured at $37^{\circ} \mathrm{C}$ and $5 \% \mathrm{CO}_{2}$ in DME/F12 medium containing $10 \%$ FBS, $5 \mu \mathrm{g} / \mathrm{ml}$ insulin, $10 \mathrm{ng} / \mathrm{ml} \mathrm{EGF,} 1 \mu \mathrm{g} / \mathrm{ml}$ hydrocortisone, Pen/Strep (100 U, $100 \mu \mathrm{g} / \mathrm{ml})$. For Matrigel culture, cells from 8 to 10-week-old virgin females were plated on Matrigel (BD Pharmingen, catalog \#354230) per well in Lab-Tek II chamber slides (catalog \#154534), cultured for 14 days, and fixed in $2 \%$ paraformaldehyde for $20 \mathrm{~min}$ at room temperature. Colonies were then permeabilized with PBS containing $0.5 \%$ Triton X-100 for 10 min at $4^{\circ} \mathrm{C}$, followed by three $10-15 \mathrm{~min}$ rinses with $\mathrm{PBS} /$ glycine (130 mM NaCl, $7 \mathrm{mM} \mathrm{Na} \mathrm{HPO}_{4}, 3.5 \mathrm{mM} \mathrm{NaH} \mathrm{PO}_{4}$; $100 \mathrm{mM}$ glycine) at room temperature. Non-specific interactions were blocked by incubating with $200 \mu \mathrm{l} /$ well of IF buffer $\left(130 \mathrm{mM} \mathrm{NaCl}, 7 \mathrm{mM} \mathrm{Na} \mathrm{HPO}_{4}, 3.5 \mathrm{mM} \mathrm{NaH}_{2} \mathrm{PO}_{4}\right.$; $7.7 \mathrm{mM} \mathrm{NaN}, 0.1 \%$ BSA, $0.2 \%$ Triton X-100, $0.05 \%$ Tween-20) containing $10 \%$ goat serum for $45-60 \mathrm{~min}$ at room temperature, after which indirect immunofluorescence was performed as described below except that images were acquired on a Zeiss LSM510-META confocal microscope.

Indirect immunofluorescence and immunohistochemistry

For embryonic studies, freshly dissected embryos were frozen in O.C.T. embedding medium (Tissue-Tek \#4583) and stored at $-80^{\circ} \mathrm{C}$ until use. Cross-sections $(6-10 \mu \mathrm{m})$ of the embryos containing the rudimentary mammary glands (\#4 except for Fig. 1a) were cut using a cryostat (Microm 
Fig. 1 K6, K8, K14 and K19 expression in embryonic mammary glands. Shown are results of indirect immunofluorescence at the indicated ages using the indicated antibodies (color-coded to match the fluorophore). DAPI stains the nuclei. Arrowhead in a points to the K6stained periderm (blue). Asterisk in c, nipple sheath. $\mathrm{mm}$, mammary mesenchyme. Red arrows in $\mathbf{c}$, e and $\mathbf{f}$ point to $\mathrm{K}^{+}$mammary cells, whereas white arrow in $\mathbf{d}$ points to $\mathrm{K} 14^{+} / \mathrm{K} 8^{+}$cells. $\mathbf{e}$, j Longitudinal sections through the inner core layers. $\mathbf{h}, \mathbf{i}, \mathbf{j}$ confocal images
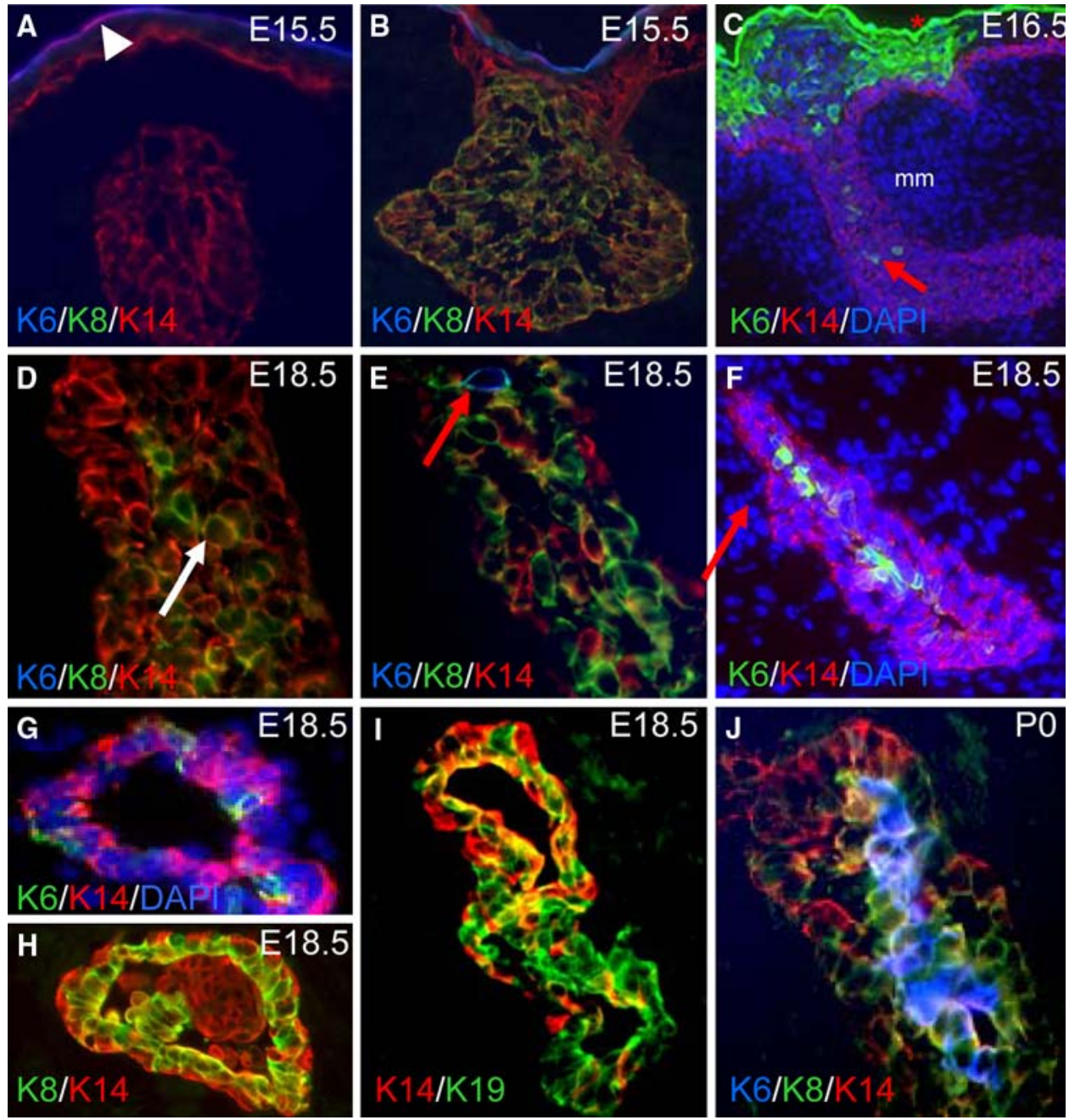

\#HM505E). For postnatal studies, fat pads containing mammary epithelia (\#3 or \#4) were dissected, and either frozen in OCT for the preparation of frozen sections, or for better morphology fixed in 4\% paraformaldehyde for $6 \mathrm{~h}$ at room temperature (see below). Frozen sections were subjected to indirect immunofluorescence as described (Dai et al. 1998). Briefly, the samples were fixed in $4 \%$ paraformaldehye for $10 \mathrm{~min}$ at room temperature, followed by 3 washes in PBS containing $0.1 \%$ Triton (PBT), 5 min each. The samples were then blocked in $20 \%$ normal goat serum in PBT containing $0.005-0.01 \%$ gelatin (NGS/gelatin). Primary antibody incubation was performed in $2 \%$ NGS/gelatin for $1 \mathrm{~h}$ to overnight, followed by a wash with $2 \% \mathrm{NGS/}$ gelatin. The following primary antibodies were used: K5 (rabbit, 1:500), K6 (rabbit, 1:500) and K14 (chicken, 1:4000), generous gifts of Julie Segre, NHGRI/NIH (Gu et al. 2009); K8 (Troma-I) and K19 (Troma-III) (rat, 1:50; Developmental Studies Hybridoma Bank). Secondary antibody incubation was in $2 \%$ NGS at room temperature for $1 \mathrm{~h}$, followed by three PBS washes. FITC-conjugated goat anti-rat, Rhodamine-conjugated goat anti-chicken and
AMCA-conjugated goat anti-rabbit secondary antibodies (Jackson ImmunoResearch) were used. The samples were then incubated with DAPI $(2 \mu \mathrm{g} / \mathrm{ml})$ for $10 \mathrm{~min}$ at room temperature, followed by three PBS washes. The slides were mounted in Antifade medium (Vectashield H-1000, Vector Laboratories), and images were taken at room temperature using a compound fluorescence microscope (Eclipse E600, Nikon) with Plan Apo 20x/0.75 NA or Plan Fluor 40x/0.75 NA objectives (Nikon), and a RT SLIDER camera equipped with SPOT 4.0.9 software (Diagnostic Instruments, Inc.). Acquired images were processed by Photoshop CS 8.0 (Adobe).

For immunohistochemistry, fixed postnatal mammary gland samples from above were washed once in PBS for $5 \mathrm{~min}$, once in $30 \%$ ethanol for $15 \mathrm{~min}$, and twice in $70 \%$ ethanol overnight. Following further washes in 95 and $100 \%$ ethanol for half an hour each, the samples were cleared with Xylene for half an hour, and then incubated and embedded in paraffin. Sections $(5 \mu \mathrm{m})$ were cut using a microtome, cleared with Histoclear (Fisher Scientific) twice for 15 min each, then rehydrated with washes of $100 \%$ 
Table 1 Summary of keratin expression during mammary gland development

\begin{tabular}{|c|c|c|c|c|c|c|c|}
\hline \multirow[t]{2}{*}{ Marker } & \multicolumn{7}{|l|}{ Age } \\
\hline & E15.5 & E18.5 & P14 & P18 & $3 \mathrm{~W}$ & $8 \mathrm{~W}$ & $12 \mathrm{~W}$ \\
\hline K5 & +++ & +++ & ba++ & ba++ & ba++ & ba++ & ND \\
\hline K6 & $+1-$ & su+ & su+ & $\mathrm{su}++$ & su++ & su+ & - \\
\hline K8 & $+1-$ & su++ & ND & ND & ND & ND & ND \\
\hline K14 & +++ & +++ & $\mathrm{ba}++/ \mathrm{su}+$ & $\mathrm{ba}++/ \mathrm{su}+$ & $\mathrm{ba}++/ \mathrm{su}+$ & ba++ & $\mathrm{ba}++$ \\
\hline
\end{tabular}

$b a$ basal, $s u$ suprabasal/luminal, +/- scattered positivity, + to +++ indicating relative abundance of positive cells, $N D$ not determined

$(2 \times 5 \mathrm{~min}), 95 \%(2 \times 5 \mathrm{~min})$, and $70 \%(1 \times 5 \mathrm{~min})$ ethanol, followed by washes with water $(1 \times 5 \mathrm{~min})$ and PBT $(1 \times 5 \mathrm{~min})$. The slides were then heated for $20 \mathrm{~min}$ in $10 \mathrm{mM}$ citrate buffer ( $\mathrm{pH}$ 6.0) in a microwave oven for antigen retrieval. Rabbit anti-K5 or K6 antibodies (primary) and biotinylated anti-rabbit $\operatorname{IgG}(\mathrm{H}+\mathrm{L})$ (Vector Laboratories, Cat: BA-1000) (secondary) were used, and signal detection was performed using the VECTASTAIN elite ABC Kit (Vector, Cat: PK-6100) and AEC (RED) single solution (Zymed, Cat: 00-1111) according to instructions from manufacturers. All immunofluorescence and immunohistochemistry experiments were performed with negative controls where no primary antibody was added.

\section{Results and discussion}

Expression of lineage-specific cytokeratins during embryonic mammary development

We first examined the expression of lineage-specific and/ or putative progenitor-associated cytokeratins, including $\mathrm{K} 6, \mathrm{~K} 8, \mathrm{~K} 14$ and K19, in embryonic mammary glands (Table 1). At E15.5 and in less developed mammary buds, only K14 expression was observed (Fig. 1a), whereas in more advanced mammary buds, most $\mathrm{K}_{14}{ }^{+}$cells began to co-express K8 (Fig. 1b). K6 expression at this stage was seen in skin periderm as expected, but was rarely detectable in mammary buds (Fig. 1a, b). At E16.5, strong K6 expression was observed in nipple sheath-in sharp contrast to the neighboring epidermal cells that normally do not express K6 protein unless upon injury (Eichner et al. 1984; Moll et al. 1982), and scattered $\mathrm{K} 6^{+}$cells were also found in nipple skin between the sheath as well as in the upper portion of the mammary sprout (Fig. 1c). Moreover, the distal border of K6 positivity coincided with the boundary of the mammary mesenchyme. By E18.5 to newborn stage, $\mathrm{K}^{+}$cells adopted a luminal-like location and were physically separated from $\mathrm{K} 14^{+}$cells, which were now mostly occupying the outer layers (Fig. 1d shows a longitudinal section through the outer layers of the primary mammary duct, whereas Fig. 1h shows a cross section).
This said, many $\mathrm{K} 14^{+}$cells were also found in the inner layers and some of them co-expressed K8 (Figs. 1e-j). At these ages (i.e., E18.5-newborn), $\mathrm{K}^{+}$cells became more abundant, and their distribution showed regional variation but an enrichment in the inner layers (Fig. 1e-g, j). Moreover, the $\mathrm{K}^{+}$cells appeared to be largely distinct from the $\mathrm{K} 14^{+}$cells. When double stained for $\mathrm{K} 14$ and $\mathrm{K} 19$, three populations were seen, including $\mathrm{K} 14^{+} \mathrm{K} 19^{+}, \mathrm{K} 14^{+} \mathrm{K} 19^{-}$, $\mathrm{K} 14^{-} \mathrm{K} 19^{+}$(Fig. 1i). Several conclusions can be drawn from these studies. First, single-lineage cells, such as those expressing only K14 or K8 or K19, are already specified during embryonic mammogenesis. Second, $\mathrm{K}^{+}, \mathrm{K}^{+} 4^{+}$ $\mathrm{K}^{+}$and $\mathrm{K} 14^{+} / \mathrm{K} 19^{+}$cells all exist in embryonic mammary glands, indicating an embryonic origin for these putative multipotent/bipotent or luminally restricted progenitor cells. Last, although emerging at a similar developmental stage, $\mathrm{K}^{+}$and $\mathrm{K} 14^{+} / \mathrm{K}^{+}$cells are overall two distinct populations of cells that likely arise independently during embryogenesis. This said, occasionally cells that are double positive for $\mathrm{K} 6$ and $\mathrm{K} 14$ or for $\mathrm{K} 6$ and $\mathrm{K} 8$ are found (data not shown).

The apparently continuous presence of $\mathrm{K}^{+}$cells from the overlying nipple skin to the opening as well as the top portion of the mammary sprout is interesting. Previously, it has been suggested based on morphological criteria that epidermal cells ingress into the mammary sprout (Veltmaat et al. 2003). The molecular similarity between the nipple skin and the upper sprout, based on the observation that they both express transcription factor Lef1 (Foley et al. 2001), is also consistent with this proposal. Our work now provides additional support for the molecular similarities between these regions. More importantly, since K6 protein expression is a hallmark of hyperproliferative keratinocytes upon wounding, our results now suggest that the formation of the nipple and the top part of mammary sprout likely involves the activation of epidermal keratinocytes. The close association of the K6-expressing epithelial territories with the underlying mammary mesenchyme suggests that the latter may secrete signals that regulate keratinocyte activation. Clearly, lineage-tracing experiments in the future will be informative in establishing a definitive relationship between the mammary sprout and its overlying epidermis. 
Moreover, additional studies are needed to elucidate the fate(s) of the putative ingressing epidermal cells and whether the $\mathrm{K}^{+}{ }^{+}$cells within the mammary sprout contribute to the subsequent morphogenesis of the gland.

K6 expression during postnatal mammary development-largely distinct from, but occasionally overlapping with K14 expression

We next examined the expression of K6 during postnatal mammary development and compared it with K14 expression (Table 1). Between P11 and P14, scattered $\mathrm{K}^{+}$cells were found, mostly in the inner core of the ductal termini, and some co-stained for K14 (Fig. 2a-c and data not shown). At P18, more prominent K6 expression was seen, particularly in inner cells of the ductal termini, and again a few cells were double positive for K6 and K14 (Fig. 2d). At 3 weeks, K6 expression was readily observed in wild-type TEB body cells and in scattered ductal epithelial cells, and $\mathrm{K}^{+} / \mathrm{K} 14^{+}$cells still existed (Fig. 2e and data not shown).
That said, most $\mathrm{K}^{+}$cells that arise between 2 and 3 weeks after birth appeared to be $\mathrm{K} 14^{-}$(Figure 2d, e). A similar pattern of expression persisted during later virgin mammary development, as abundant $\mathrm{K}^{+}$cells were still seen in both ductal termini and ducts of 8 -week mammary glands, whether assayed by immunofluorescence on frozen sections or immunohistochemistry on paraffin sections (Fig. 2g, h and data not shown). Upon maturation, however, K6 expression became virtually undetectable (Fig. 2f), a finding that is consistent with previous reports ( $\mathrm{Gu}$ et al. 2009; Li et al. 2003; Smith et al. 1990). These results indicate that, as during embryonic development, postnatal mammary $\mathrm{K}^{+}$cells constitute an overall distinct population from $\mathrm{K} 14^{+}$cells. However, the developing mammary glands in virgin females also contain a small number of $\mathrm{K} 6^{+} / \mathrm{K} 14^{+}$cells. These double positive cells may share the same developmental potential as the suprabasal/luminal $\mathrm{K} 6 / \mathrm{K} 14-$ coexpressing cells that are detected in pregnant and lactating glands and proposed to be mammogenic stem cells (Smith et al. 1990). Whether $\mathrm{K}^{+} / \mathrm{K}_{1} 4^{+}$and $\mathrm{K}^{+} / \mathrm{K} 14^{-}$
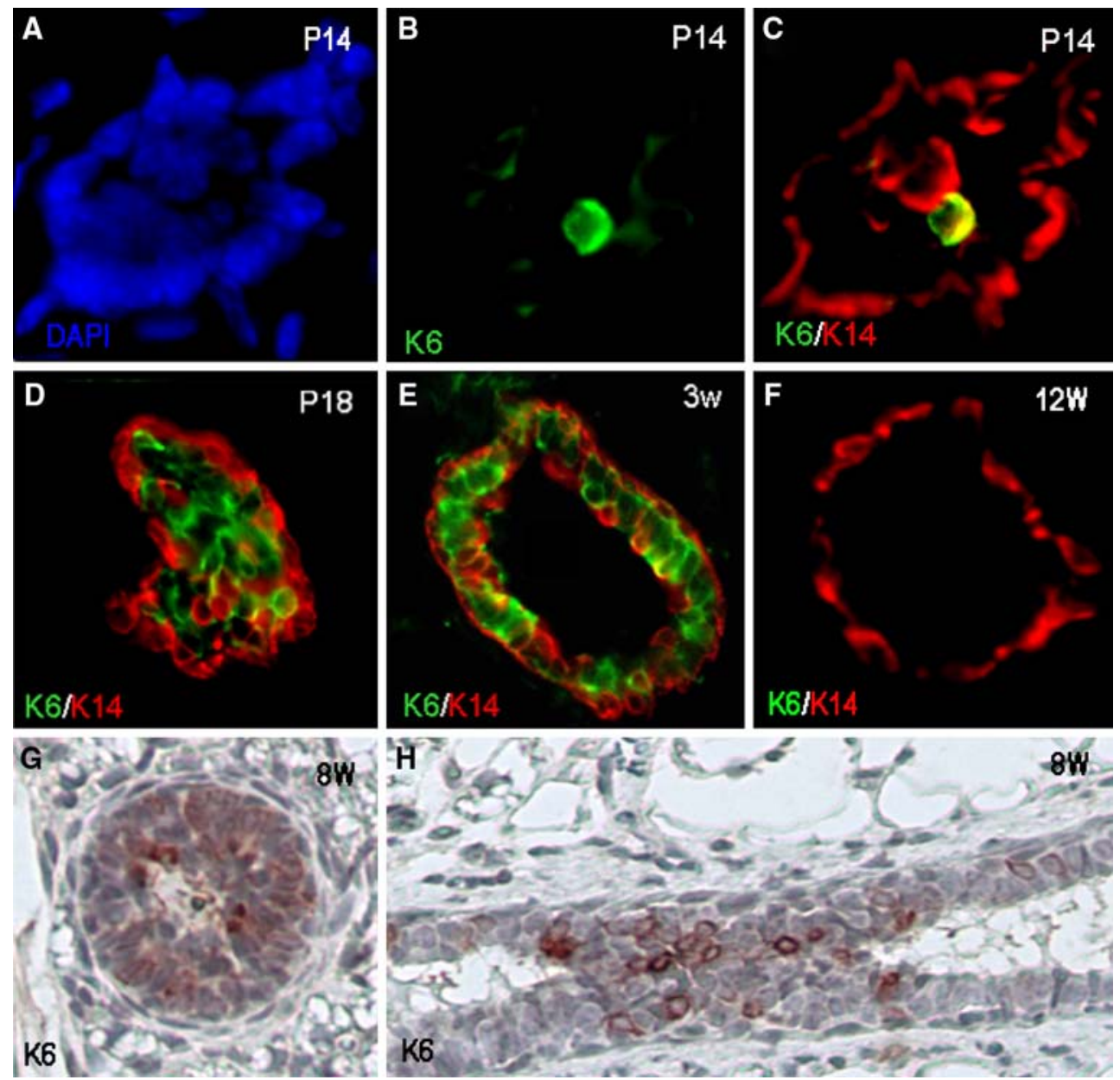

Fig. 2 K6 expression in postnatal virgin mammary glands. Shown are paraffin sections using only K6 antibody $(\mathbf{g}, \mathbf{h})$ at the indicated ages. results of indirect immunofluorescence on frozen sections using K6 For P14 analysis, DAPI staining (a) visualizes the nuclei; (b) shows K6 (green) and K14 (red) antibodies (a-f) or immunohistochemistry on staining while (c) is the corresponding merged image 
cells are progenitor populations that differ in developmental potency is an interesting question for future investigation.

Previously, Mikaelian et al. were not able to detect any K6 expression at any stage of the mammary gland development, and concluded that $\mathrm{K} 6$ is not a marker of the mammary gland stem cell (Mikaelian et al. 2006). However, our study of multiple stages of development clearly revealed the presence of K6-expressing cells. This said, we observed only scattered $\mathrm{K}^{+}$cells in most regions of embryonic and early postnatal mammary glands, whereas Grimm et al. reported that nearly all cells in their cross sections of embryonic mammary gland stained positive for K6 (Grimm et al. 2006). As the same antibody is used in both studies, we surmise that our data looking at multiple regions and multiple stages present a more accurate and comprehensive picture of K6 expression in developing mammary glands. Alternatively, the difference may be due to methods in antigen retrieval or mouse strains.

Expression of K5 and K14 overlaps in basal/myoepithelial cells throughout mammary development, with additional K14 expression detected in many suprabasal/luminal cells between 2 and 3 weeks after birth

Although K5 and K14 are both lineage markers of mammary basal/myoepithelial cells, the promoters of the corresponding genes when used to drive Cre recombinasedirected overexpression of the same protein resulted in different mammary phenotypes ( $\mathrm{Gu}$ et al. 2009; Teuliere et al. 2005). This prompted us to carefully compare their expression throughout embryonic and postnatal mammary gland development using double immunofluorescence (Table 1). At E15.5 and E18.5, nearly all epithelial cells expressed both K5 and K14, with some cells displaying stronger K14 while others stronger K5 signals (Fig. 3a, b). The same was true at P11 (Fig. 3c). At P14 and P18, the outer basal/myoepithelial cells expressed both K5 and K14, whereas some suprabasal/luminal cells expressed K14 but not K5 (Fig. 3d, e). Suprabasal/luminal K5 ${ }^{-} \mathrm{K} 14^{+}$cells persisted until 3 weeks, with the abundance of such cells varying from section to section depending on distance from the TEB (Fig. 3f and data not shown). The number of suprabasal/luminal $\mathrm{K}^{+} 4^{+}$cells dramatically decreased after 3 weeks, such that in adult mammary glands (8-12 weeks), few such cells were found (Fig. $3 g$ ). From the ages of P14 to adult and for all sections analyzed with either immunofluorescence on frozen sections or immunohistochemistry on paraffin sections, K5 expression was near-completely confined to the basal compartment (Fig. 3d-h). Together, these results show that in addition to the basal compartment, K14, but not K5, was transiently expressed in the suprabasal/luminal compartment of pre-pubertal mammary epithelium.
Our finding of K5 expression in embryonic and prepubertal mammary glands contrasts a previous study reporting that the first stage of $\mathrm{K} 5$ expression in mammary glands is postnatal day 21 while K14 is expressed as earlier as E13.5 (Mikaelian et al. 2006). The use of different antibodies and different efficiency of staining methods likely underlie this discrepancy. A temporal and spatial overlap of K5 and K14 expression during mammary development is more consistent with previous findings that $\mathrm{K} 5$ is the main partner of K14 and that the two genes largely co-express in the epidermis (Byrne et al. 1994; Purkis et al. 1990).

The transient expression of K14 in the suprabasal/luminal compartment is consistent with previous observation of $\mathrm{K} 14^{+} / \mathrm{K}^{+}$suprabasal/luminal cells that are found infrequently in adult mammary glands and proposed to be stem/ progenitor cells (Li et al. 2007). Our comparative expression analysis shows that suprabasal/luminal $\mathrm{K} 14^{+}$cells disappear earlier during postnatal mammary epithelial development than the putative $\mathrm{K}^{+}$progenitor cells. If $\mathrm{K}^{+}$and suprabasal/ luminal $\mathrm{K}_{14}{ }^{+}$cells are indeed progenitor cells as previously proposed, then our finding would suggest that different pools of progenitor cells might be used at different developmental stages to contribute to distinct morphogenetic processes.

Our detailed analysis of K5/K14 expression in the developing mammary gland now provides a possible explanation for the aforementioned phenotypic differences between mouse models using K5 or K14 promoter to drive genetic alterations in mammary glands. Although past mammary studies focused heavily on the use of hormonally responsive promoters, such as MMTV and WAP, to direct gene expression or ablation, the use of K5 and K14 promoters has become increasingly popular as this allows targeting of genetic changes to developmental mammary stem/progenitor cells (Berton et al. 2003; Choi et al. 2009; Gu et al. 2009; Taddei et al. 2008). In this context, our expression data offer a useful guide on exactly when and where the desired genetic changes would occur-information needed for predicting and interpreting phenotypic outcomes.

$\mathrm{K} 5 / \mathrm{K} 6 / \mathrm{K} 14$ expression in cultured primary mammary epithelial cells mimics the expression pattern in vivo

Primary mammary epithelial cells (MEC) can be cultured from mammary glands and serve as a useful in vitro model for mechanistic studies. We therefore cultured MEC cells and analyzed their expression of $\mathrm{K} 5, \mathrm{~K} 6$ and $\mathrm{K} 14 . \mathrm{K}^{+}$, $\mathrm{K}^{+}$, or $\mathrm{K} 14^{+}$cells were readily detected in MEC culture, even in those derived from mature mammary glands that normally do not contain an appreciable number of $\mathrm{K}^{+}$cells in vivo (Fig. $4 \mathrm{a}-\mathrm{c}$ and data not shown). In a representative experiment, approximately half $(51 \pm 7 \%)$ of $\mathrm{K}_{14}{ }^{+}$cells also expressed $\mathrm{K} 5$, whereas all $\mathrm{K}^{+}$cells expressed $\mathrm{K} 14$. Therefore, $\mathrm{K} 5$ and $\mathrm{K} 14$ expression during in vitro passaging 
Fig. 3 Double immunofluorescence analysis of K5 and K14 expression in embryonic and postnatal mammary glands. Shown are results of indirect immunofluorescence on frozen sections using K5 (green) and K14 (red) antibodies (a-g) or immunohistochemistry on paraffin sections using only $\mathrm{K} 5$ antibody (h). DAPI (blue) stains the nuclei. Arrows point to suprabasal/luminal $\mathrm{K} 4^{+}(\mathbf{d}-\mathbf{f})$ cells
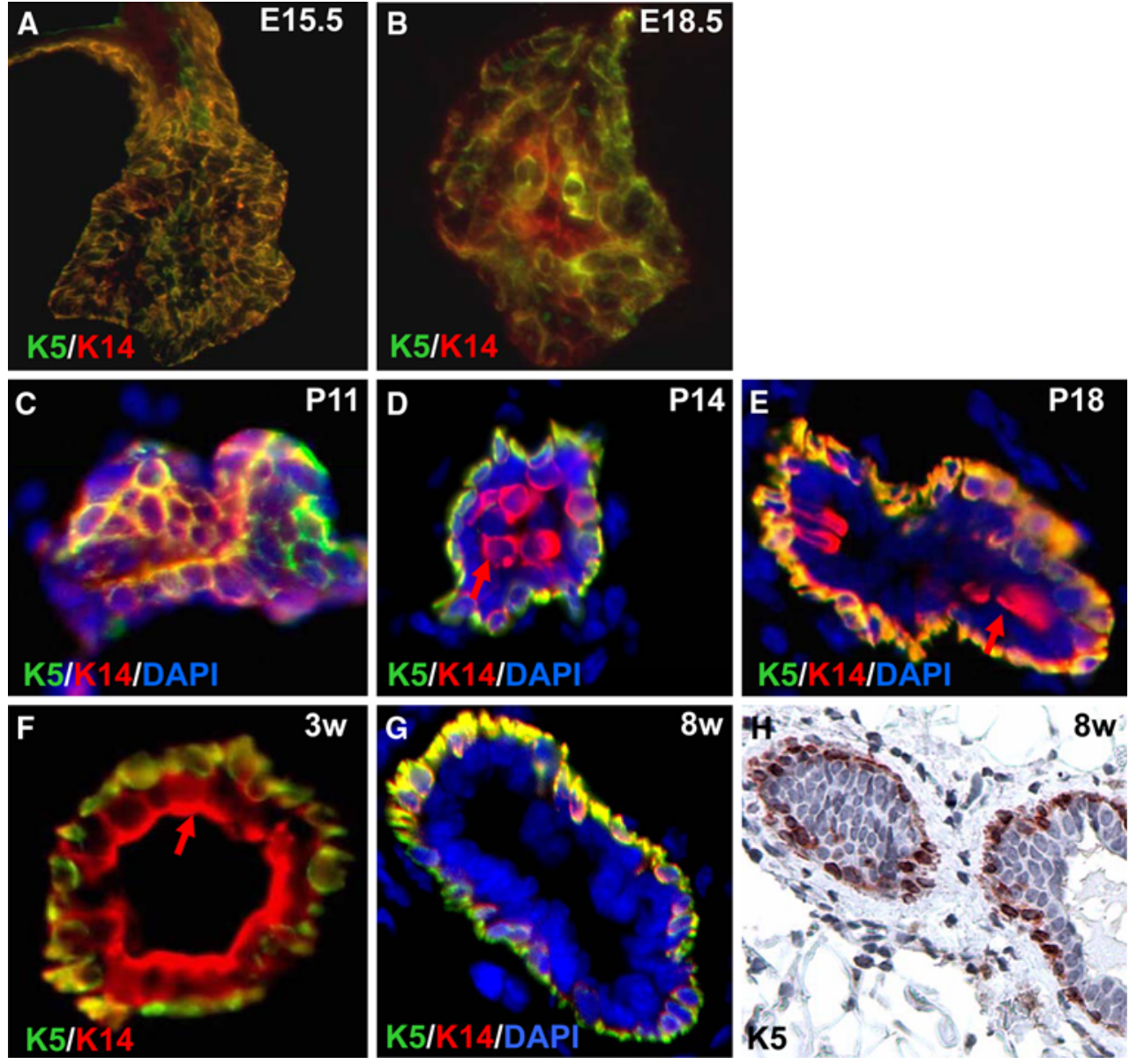

of $\mathrm{K}^{-} \mathrm{K} 6^{+} \mathrm{K} 14^{+}$cells associates with a phase of active cell proliferation and tissue growth. Previously, Tyner and Fuchs showed that K6 and K14 expression is higher in cultured keratinocytes than in skin epidermis (Tyner and Fuchs 1986). Therefore, increased K6 expression upon in vitro culture seems to be a common feature of at least two different epithelial cell lineages.

We also examined K6 expression in colonies formed on Matrigel. Primary MEC cells produced different types of colonies: some were large and composed of both solid and irregular lumen-containing structures (Fig. 4d, e), while others were either solid (Fig. 4f, g) or showing a round acinar morphology reminiscent of those formed by more differentiated luminal progenitor cells (Fig. 4h, i) (Stingl et al. 2006). The large, mixed-type colonies are likely formed by stem and/or early progenitor cells (Stingl et al. 2006). Altogether, we detected K6 expression in 59-71\% of the total colonies examined. In the mixed-type colonies, cells with strong K6 expression were predominantly found clustered in the solid portion, showing a preference for outside locations (Fig. 4d, e). Scattered strong $\mathrm{K}^{+}$cells or weakly stained cells were also found in the epithelia lining the irregular lumen in these colonies (Fig. 4d). K6 expression was also detected in standing-alone solid colonies (Fig. 4f, g),
$\mathrm{K} 14^{+}$cells. Finally, the cellular dynamics that we observed in vivo and in culture raises the possibility that an abundance 

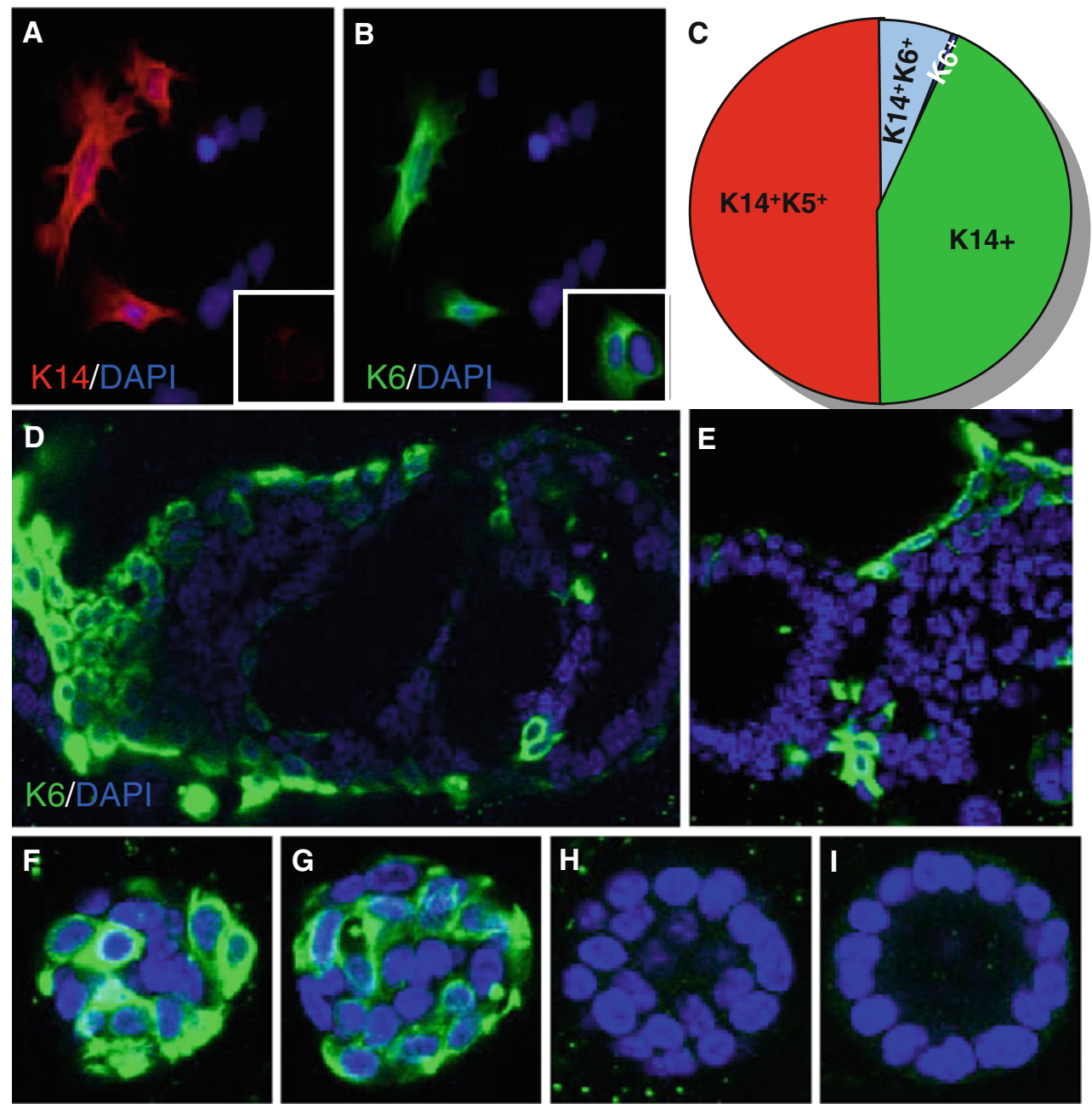

Fig. 4 K5/K6/K14 expression in cultured primary MEC cells. a, b Double immunofluorescence of cells from a 13-month-old female using $\mathrm{K} 14$ (a, red) and K6 (b, green) antibodies. Insets show a dividing cell that is $\mathrm{K}^{+}$but $\mathrm{K}_{14}{ }^{-}$. $\mathrm{c}$ Pie diagram showing the percent distribution of $\mathrm{K} 5, \mathrm{~K} 6$, and $\mathrm{K} 14$ expressing cells. The area of the circle equals the total number of cells that express either K5, K6, or K14, or a com-

but rarely seen in the spherical acinar structures (Fig. 4h, i). Collectively, our results reveal $\mathrm{K}^{+}$cells in two different cell culture models, namely monolayer and Matrigel, and demonstrate an association of K6 expression with the in vitro differentiation activity of mammary stem/progenitor cells.

In summary, we present a comparative analysis of cytokeratin expression during embryonic and postnatal mammary development. Our study provides evidence for an embryonic origin of putative mammary stem/progenitor cells and informs the use of specific cytokeratins as markers of mammary epithelial differentiation, as well as the use of their promoters to direct desired genetic alterations.

Acknowledgments We thank Julie Segre for $\alpha \mathrm{K} 6, \alpha \mathrm{K} 5$ and $\alpha \mathrm{K} 14$ antibodies and Jacqueline Veltmaat for discussions. This work was supported by DOD grant W81XWH-04-1-0516, and NIH Grants R01-AR47320, R01-GM083089, and K02-AR51482 (to X.D.),

bination of them. Data shown are taken from cultures fixed at day 9 after the initial plating. d-i Confocal images of K6 (green) and DAPI (blue) immunofluorescence on Matrigel colonies formed by MEC cells from 8 to 10 -week-old females. Shown in $\mathbf{f}$ and $\mathbf{g}$ or $\mathbf{h}$ and $\mathbf{i}$ are $z$-sections at two different planes of the same colony

National Key Research Project of Basic Sciences of China (973 project 2006CB708507) and the National Natural Science Foundation of China (30671173) (to B.L.).

Open Access This article is distributed under the terms of the Creative Commons Attribution Noncommercial License which permits any noncommercial use, distribution, and reproduction in any medium, provided the original author(s) and source are credited.

\section{References}

Ball SM (1998) The development of the terminal end bud in the prepubertal-pubertal mouse mammary gland. Anat Rec 250:459-464

Bartek J, Bartkova J, Taylor-Papadimitriou J (1990) Keratin 19 expression in the adult and developing human mammary gland. Histochem J 22:537-544

Berton TR, Matsumoto T, Page A, Conti CJ, Deng CX, Jorcano JL, Johnson DG (2003) Tumor formation in mice with conditional 
inactivation of Brcal in epithelial tissues. Oncogene 22:54155426

Byrne C, Tainsky M, Fuchs E (1994) Programming gene expression in developing epidermis. Development 120:2369-2383

Choi YS, Chakrabarti R, Escamilla-Hernandez R, Sinha S (2009) Elf5 conditional knockout mice reveal its role as a master regulator in mammary alveolar development: failure of Stat5 activation and functional differentiation in the absence of Elf5. Dev Biol 329:227-241

Dai X, Schonbaum C, Degenstein L, Bai W, Mahowald A, Fuchs E (1998) The ovo gene required for cuticle formation and oogenesis in flies is involved in hair formation and spermatogenesis in mice. Genes Dev 12:3452-3463

Eichner R, Bonitz P, Sun TT (1984) Classification of epidermal keratins according to their immunoreactivity, isoelectric point, and mode of expression. J Cell Biol 98:1388-1396

Foley J, Dann P, Hong J, Cosgrove J, Dreyer B, Rimm D, Dunbar M, Philbrick W, Wysolmerski J (2001) Parathyroid hormone-related protein maintains mammary epithelial fate and triggers nipple skin differentiation during embryonic breast development. Development 128:513-525

Grimm SL, Bu W, Longley MA, Roop DR, Li Y, Rosen JM (2006) Keratin 6 is not essential for mammary gland development. Breast Cancer Res 8:R29

Gu B, Sun P, Yuan Y, Moraes RC, Li A, Teng A, Agrawal A, Rheaume C, Bilanchone V, Veltmaat JM, Takemaru K, Millar S, Lee EY, Lewis MT, Li B, Dai X (2009) Pygo2 expands mammary progenitor cells by facilitating histone H3 K4 methylation. J Cell Biol 185:811-826

Hennighausen L, Robinson GW (2001) Signaling pathways in mammary gland development. Dev Cell 1:467-475

Kenney NJ, Smith GH, Lawrence E, Barrett JC, Salomon DS (2001) Identification of stem cell units in the terminal end bud and duct of the mouse mammary gland. J Biomed Biotechnol 1:133-143

Li Y, Welm B, Podsypanina K, Huang S, Chamorro M, Zhang X, Rowlands T, Egeblad M, Cowin P, Werb Z, Tan LK, Rosen JM, Varmus HE (2003) Evidence that transgenes encoding components of the Wnt signaling pathway preferentially induce mammary cancers from progenitor cells. Proc Natl Acad Sci USA 100:15853-15858

Li Z, Tognon CE, Godinho FJ, Yasaitis L, Hock H, Herschkowitz JI, Lannon CL, Cho E, Kim SJ, Bronson RT, Perou CM, Sorensen PH, Orkin SH (2007) ETV6-NTRK3 fusion oncogene initiates breast cancer from committed mammary progenitors via activation of AP1 complex. Cancer Cell 12:542-558

Mikaelian I, Hovick M, Silva KA, Burzenski LM, Shultz LD, AckertBicknell CL, Cox GA, Sundberg JP (2006) Expression of terminal differentiation proteins defines stages of mouse mammary gland development. Vet Pathol 43:36-49
Moll R, Franke WW, Schiller DL, Geiger B, Krepler R (1982) The catalog of human cytokeratins: patterns of expression in normal epithelia, tumors and cultured cells. Cell 31:11-24

Moll R, Divo M, Langbein L (2008) The human keratins: biology and pathology. Histochem Cell Biol 129:705-733

Purkis PE, Steel JB, Mackenzie IC, Nathrath WB, Leigh IM, Lane EB (1990) Antibody markers of basal cells in complex epithelia. J Cell Sci 97(Pt 1):39-50

Sapino A, Macri L, Gugliotta P, Pacchioni D, Liu YJ, Medina D, Bussolati G (1993) Immunophenotypic properties and estrogen dependency of budding cell structures in the developing mouse mammary gland. Differentiation 55:13-18

Shackleton M, Vaillant F, Simpson KJ, Stingl J, Smyth GK, AsselinLabat ML, Wu L, Lindeman GJ, Visvader JE (2006) Generation of a functional mammary gland from a single stem cell. Nature 439:84-88

Smith GH, Mehrel T, Roop DR (1990) Differential keratin gene expression in developing, differentiating, preneoplastic, and neoplastic mouse mammary epithelium. Cell Growth Differ 1:161170

Stasiak PC, Purkis PE, Leigh IM, Lane EB (1989) Keratin 19: predicted amino acid sequence and broad tissue distribution suggest it evolved from keratinocyte keratins. J Invest Dermatol 92:707716

Stingl J, Eirew P, Ricketson I, Shackleton M, Vaillant F, Choi D, Li HI, Eaves CJ (2006) Purification and unique properties of mammary epithelial stem cells. Nature 439:993-997

Taddei I, Deugnier MA, Faraldo MM, Petit V, Bouvard D, Medina D, Fassler R, Thiery JP, Glukhova MA (2008) Beta1 integrin deletion from the basal compartment of the mammary epithelium affects stem cells. Nat Cell Biol 10:716-722

Teuliere J, Faraldo MM, Deugnier MA, Shtutman M, Ben-Ze'ev A, Thiery JP, Glukhova MA (2005) Targeted activation of beta-catenin signaling in basal mammary epithelial cells affects mammary development and leads to hyperplasia. Development 132:267277

Tyner AL, Fuchs E (1986) Evidence for posttranscriptional regulation of the keratins expressed during hyperproliferation and malignant transformation in human epidermis. J Cell Biol 103:1945-1955

Veltmaat JM, Mailleux AA, Thiery JP, Bellusci S (2003) Mouse embryonic mammogenesis as a model for the molecular regulation of pattern formation. Differentiation 71:1-17

Villadsen R, Fridriksdottir AJ, Ronnov-Jessen L, Gudjonsson T, Rank F, LaBarge MA, Bissell MJ, Petersen OW (2007) Evidence for a stem cell hierarchy in the adult human breast. J Cell Biol 177:87101

Woodward WA, Chen MS, Behbod F, Rosen JM (2005) On mammary stem cells. J Cell Sci 118:3585-3594 